\title{
Localised and regional patterns in ground-dwelling beetle assemblages in a semi-tropical arid zone environment
}

\author{
Nadine A. Guthrie ${ }^{1 *}$, Tom Weir ${ }^{2}$ and Kipling Will ${ }^{3}$ \\ ${ }^{1}$ Department of Environment and Conservation, PO Box 51, Wanneroo, Western Australia 6946, Australia. \\ Email: Nadine.Guthrie@dec.wa.gov.au \\ ${ }^{2}$ Australian National Insect Collection, CSIRO Entomology, GPO Box 1700, Canberra, Australian Capital Territory, 2601, \\ Australia. \\ ${ }^{3}$ ESPM Department \& Essig Museum of Entomology, University of California, Berkeley, California, U.S.A.
}

\begin{abstract}
Ground-dwelling beetles were sampled by pitfall traps at 304 quadrats positioned to represent the geomorphic extent and profile of the Pilbara Region, a semi-tropical arid region in north-west Western Australia. For each quadrat, 47 climatic, soil, landform, geological and vegetation attributes were determined. A total of 429 taxa across the Bolboceratidae, Carabidae, Hybosoridae, Scarabaeidae and Tenebrionidae were identified, of which $68 \%$ could not be assigned to currently recognised species.

Species richness ranged from 1 to 36 species per quadrat, with an average of $11.6 \pm 5.9$ species $(n=296$ quadrats). Species recorded at one quadrat only ('singletons') constituted $33 \%$ of the fauna and were collected mainly from areas near the edge of the region or were associated with the Fortescue subregion; they included $36 \%$ of the Bolboceratidae (8 species), $32 \%$ of the Carabidae (72 species), 33\% of the Hybosoridae (2 species), $46 \%$ of the Scarabaeidae (45 species) and $22 \%$ of the Tenebrionidae (17 species). Those from the region's edge may have their distributions centred elsewhere, while singletons from the Fortescue subregion may be restricted to marsh habitats that are rare elsewhere in the region.

Locally, compositional patterns were correlated with landform and soil attributes (slope, soil depth, exchangeable calcium, exchangeable potassium and sandiness). Heavy cracking clays, and saline and riverine-associated muds, supported a distinctive suite of species, from which the more widespread or common species were generally absent. At the regional scale, patterns in composition reflected the region's physio-geographical subregions. Localised evolutionary processes associated with and promoting low mobility have resulted in fauna with a high proportion of strongly-localised endemic forms. Detailed comparisons of the beetle fauna with neighbouring semi-arid areas such as the Great and Little Sandy Deserts, Ashburton and Northern Carnarvon Basin are required to determine phylogenetic relationships between taxa, distributions, and to explore further the correlation of species composition with various land attributes that have emerged from our analysis.
\end{abstract}

Key Words - Bolboceratidae, Carabidae, Hybosoridae, Scarabaeidae, Tenebrionidae, Pilbara, biogeography, biodiversity, pitfall traps, regional survey, species richness

\section{INTRODUCTION}

Attempts to estimate and document terrestrial beetle (and other insect) species richness in Australia have been affected by the state of taxonomic knowledge, in addition to difficulties in access to many habitats and environments (Austin et al. 2004). This biodiversity information has direct application in biogeographical surveys, environmental monitoring, conservation and diversity assessment studies (e.g. Solem and
McKenzie 1991; Margules 1992; Abensperg-Traun et al. 1996; Michaels 1999; Davies and Margules 2000; Harvey et al. 2004; Gibson and New 2007). However, the use of terrestrial invertebrates in contemporary Australian surveys is still constrained by problems associated with taxonomic resolution and a lack of ecological and faunistic information (New 1998).

The major causative agents driving the high beetle (and insect) diversity in the Pilbara, and across Australia as a whole, are, in combination, the large size of the continent, extremely long 
geological isolation, and repeated retreat and expansion of rainforests with radiation of Eucalyptus and Acacia communities in response to Miocene aridification (also reflected in other Australian fauna and flora; Hopper et al. 1996; Main 1996, 2000; Cowling and Lamont 1998; Beard et al. 2000; Austin et al. 2004; Ślipiński 2007).

These agents have led to a tendency towards many localised species, with a high proportion being flightless, reflecting limited available habitat but within a generally stable environment (Matthews 1974; Howden 1981; Baehr 2005). An example of such an environment is the Pilbara, which experiences radical short-term substrate changes due to floods, but is very stable over decades and greater time spans, and it has not changed significantly in its structure through much of the Tertiary (Baehr 2005).

Earlier collecting of beetles in Australia has been sporadic, and opportunistic, with many very early collections consisting of single or few isolated specimens (e.g. Western Australian Museum records, Australian National Insect Collection records). This has inhibited assessment of species distributions and relationships between taxa. More recently, localised, isolated, opportunistic and restricted surveys have been carried out, usually focusing on a taxon or habitat (e.g. Baehr 1990; Majer and Recher 1988 and others). These studies have indicated that, even in habitats such as beneath hanging tree bark in semi-arid and arid zones, there is high beetle diversity (Baehr 1990).

As these surveys and collections are isolated in time and context, their usefulness as baseline information for contemporary surveys and conservation and diversity assessment studies is limited. Therefore, as a component of a large study documenting the biodiversity patterns in the Pilbara biogeographic region of Western Australia, data on the ground-dwelling terrestrial beetle fauna were collected. This was the first opportunity to survey the region systematically for beetles. This has provided baseline information on distribution, taxonomy and morphological variability for future surveys and monitoring programs. Specifically, the Bolboceratidae, Carabidae, Hybosoridae, Scarabaeidae and Tenebrionidae were chosen as representatives of the ground-dwelling beetle fauna, for assessment of assemblage structure and species turnover across the Pilbara landscape in terms of geographic, climatic and substrate attributes. This decision was based on information from previous surveys, relatively stable taxonomy and representativeness of generalised feeding

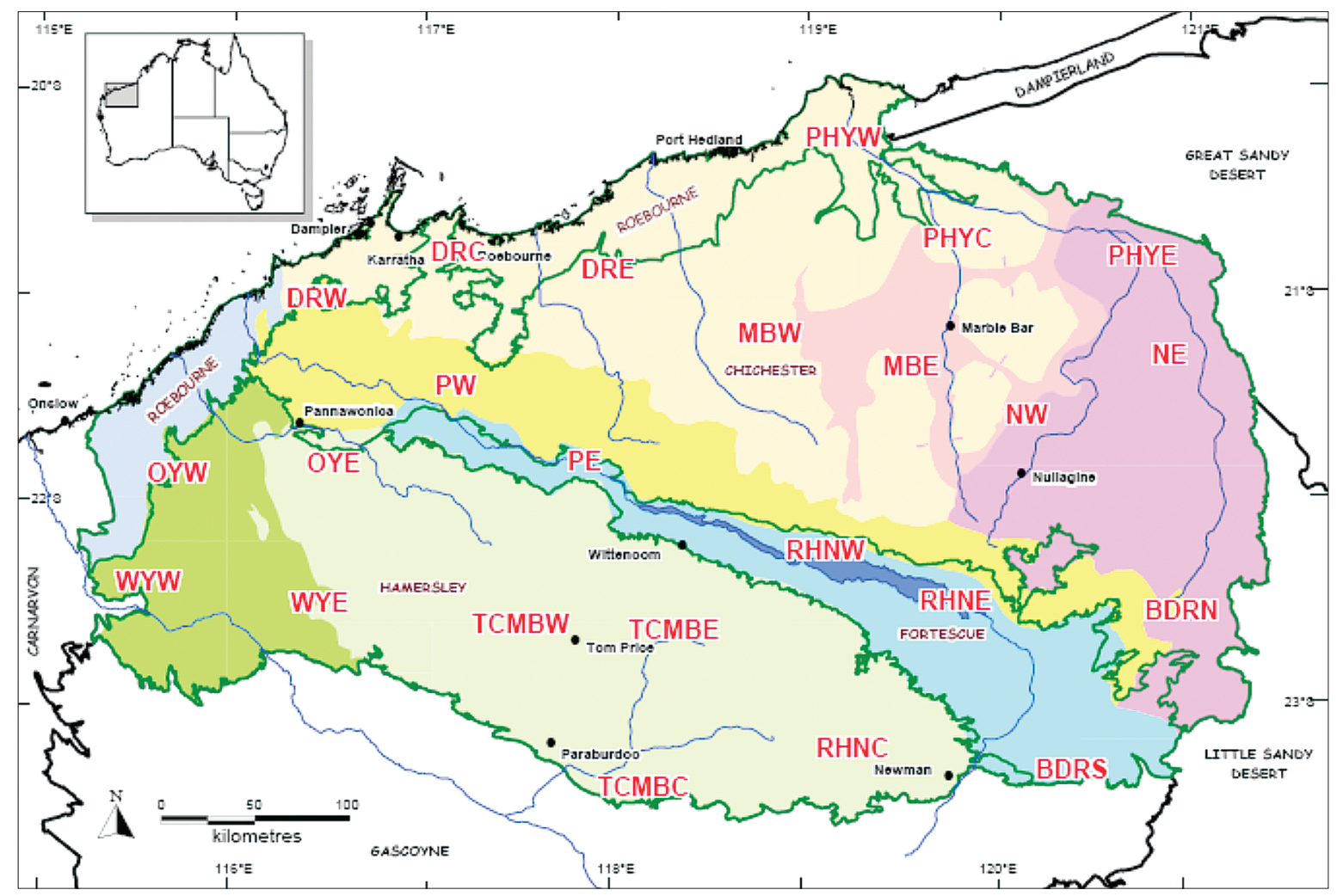

Figure 1 Map of the Pilbara showing a) locations of Survey Cells, b) boundaries of the four IBRA subregions outlined in green, c) the eight physio-geographical subregions recognised by Beard (1975): Oakover Valley - dark pink, central Gorge Range - pale pink, Abydos Plain - beige, Chichester Plateau - yellow; Fortescue - pale blue; Hamersley Range - pale green, Stuart Hills - green, Onslow Plain - mauve, d) major rivers - dark blue and towns. 
niches (Naumann, Weir and Edwards 1991; Lawrence and Britton 1994; Bouchard and Yeates 2001; Cassis and Weir 2002; Matthews and Bouchard 2007).

\section{METHODS}

\section{Survey region}

Encompassing the Pilbara Craton, the Pilbara IBRA biogeographic region is situated in the north-west of Western Australia, and covers approximately $179,000 \mathrm{~km}^{2}$ (Figure 1). It has a semidesert tropical climate, becoming arid on the coast and towards the north-east interior. Rainfall is highly variable year to year and across the region, averaging circa $300 \mathrm{~mm}$, provided mainly by summer cyclonic events (May and McKenzie 2003). Geology and vegetation communities differ across the four distinct subregions: Chichester, Fortescue, Hamersley and the Roebourne Plains (Figure 1; Beard 1990; Environment Australia 2008). McKenzie et al. (2009) describe the climatic, geophysical and vegetation characteristics of the Pilbara in detail so only a brief description is given below.

The Chichester subregion, occupying the northern Pilbara Craton, consists of undulating Archaean granite and basalt plains and ranges. Several rivers drain the northern Chichester (De Grey, Oakover, Nullagine, Shaw, Yule and Sherlock). Beard (1975) subdivided the subregion further into the Oakover Valley in the east; central Gorge Range; Abydos Plain in the western third plus the northern Roebourne Plain; and the Chichester Plateau as separate physiographic units (Figure 1). Broadly speaking, these physiographic units consist of Acacia inaequilatera shrub steppes over Triodia wiseana hummock grasslands on the plains, and snappy gum (Eucalyptus leucophloia) tree steppe in the ranges (May and McKenzie 2003).

Dissected by deep gorges in the west, the Fortescue subregion has drainage lines fringed with river red gum (Eucalyptus camaldulensis) woodlands, and salt marshes, mulga-bunch and short grass communities on the eastern alluvial plains. River red gum and cadjeput (Melaleuca) woodlands occur along permanent springs and wetlands in the central Fortescue (May and McKenzie 2003).

The Hamersley subregion overlies the southern Pilbara Craton and features Proterozoic sedimentary ranges and plateaux dissected by gorges. It is drained by the Fortescue River in the north, Ashburton in the south and the Robe River to the west. The Stuart Hills and remaining Hamersley Plateau were identified as separate physiographic units by Beard (1975). Both units have snappy gum over Triodia brizoides hummock grasslands dominating the ranges, with Mulga
(Acacia aneura sens. lat.) low woodland over bunch grasses on the plains.

The Roebourne subregion delineates the western coastal plain of the Pilbara. Linear basalt ranges with exposed granite dissect Quaternary alluvial and older colluvial coastal plains (May and McKenzie 2003). Beard (1975) identified the Onslow Central Plain as a distinct physiographic unit of the Roebourne Plain, with the northern section of this subregion as part of the Abydos Plain. Triodia hummock grasses occur on the ranges, with Eucalyptus victrix or Corymbia hamersleyana woodlands on ephemeral drainage lines. Bunch and hummock grass savannahs with Acacia stellaticeps, A. pyrifolia and A. inaequilatera dwarf shrub steppe characterise the plains, with samphire, Sporobolus and mangal communities present on the river deltas and surrounding flats (May and McKenzie 2003).

\section{Sampling strategy}

The region was divided into 24 survey cells that together encompassed the geographical and environmental variation of the Pilbara (Figure 1). In each survey cell, 11 to 13 quadrats were positioned to represent examples of the major habitats on the major landforms, choosing sites least disturbed by human use, stock or fire. The 304 quadrats across the region were positioned to sample the main components of the Pilbara's geomorphic profile. Where possible, quadrats were pseudo-replicated between survey cells and within individual areas for the more extensive geomorphic units. For each quadrat, climatic attributes were derived and physical attributes including landform, soil chemical and texture values and vegetation were assessed; these are provided in Appendices A-D of McKenzie et al. (2009).

To reduce bias associated with variations in climate and bushfire damage, quadrat establishment and sampling occurred in separate years in a chessboard pattern of the 24 survey cells (Figure 2). Twelve survey cells were established with pitfall traps opened mid-2003 and closed late2004, while the second series of 12 survey cells was sampled between mid-2005 and late-2006. Thus, the average length of sampling across all quadrats was 395 days each $(n=304$ quadrats; $\min =309$, $\max =$ 461; sampling dates are provided in Appendix 1). This reduced the bias associated with sampling for short periods (such as a few weeks in a single season).

Each $50 \times 50 \mathrm{~m}$ quadrat consisted of five pitfall traps: one at each corner and one in the middle (Figure 3). Each pitfall trap consisted of a 2 litre, UV resistant plastic container $(80 \mathrm{~mm}$ neck diameter) inserted into a PVC sleeve dug into the ground, flush with the ground surface. To form a continuous 


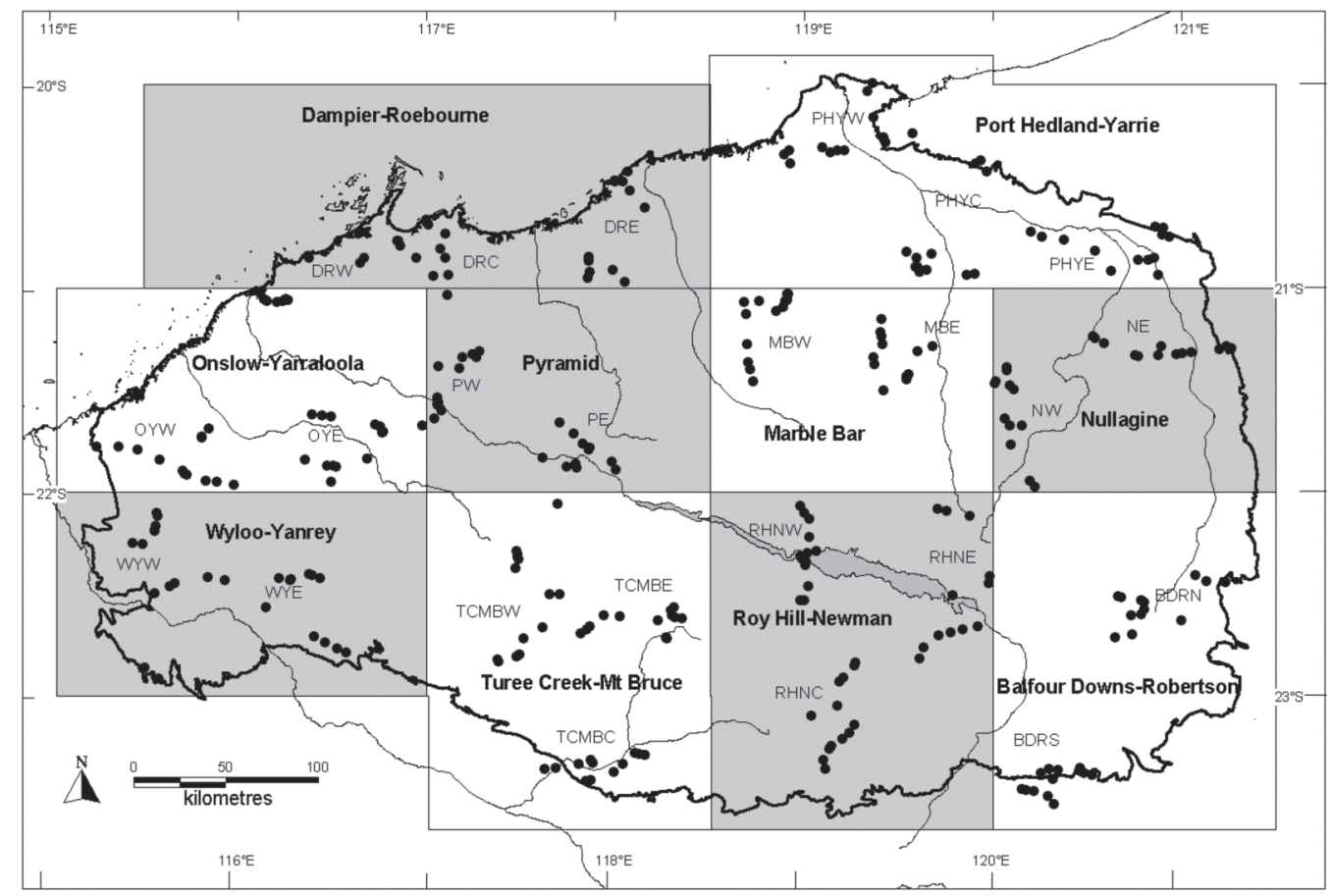

Figure 2 Map of the Pilbara showing a) locations of Survey Cells, b) 304 quadrats, and c) chessboard sampling of survey cells in two sets of 12 cells: cells sampled between mid-2003 and late-2004 highlighted in grey, and survey cells sampled between mid-2003 and late-2004 in white.

surface between the ground and jar lip, an acrylic ring covered in glued sand was attached between the PVC sleeve and jar lip. Two hoop iron stands fitted between the PVC sleeve and jar supported a $200 \times 200 \mathrm{~mm}$ colourbond roof approximately 4 $\mathrm{cm}$ above the ground surface. One litre of ethylene glycol mixed with $4 \%$ formalin was used as the preserving fluid in each pitfall trap. Each pitfall trap was collected and reset at least once during

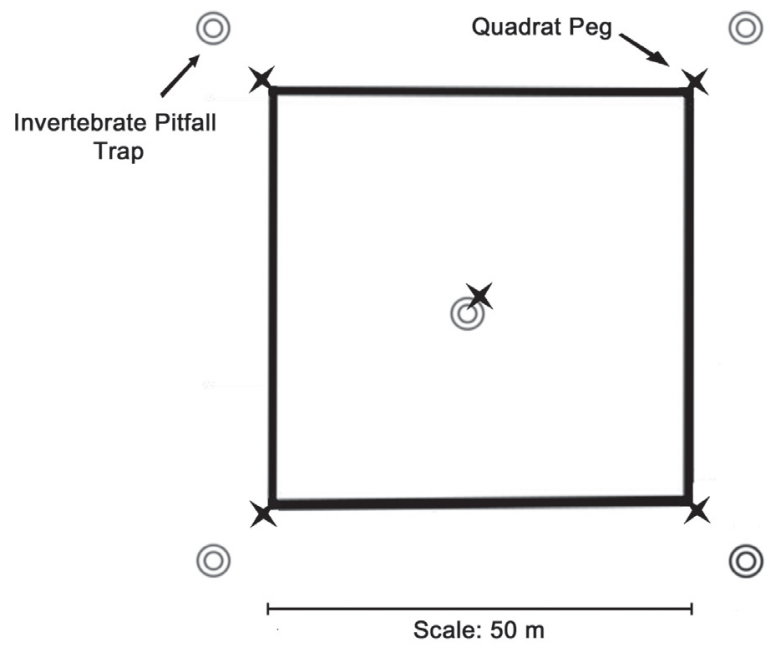

Figure 3 Design of quadrat, showing position of botanical quadrat, and invertebrate pitfall traps. the surveying period (Appendix 1). Samples were returned to the laboratory, washed in water and stored in $75 \%$ ethanol until sorting, processing and identification.

\section{Taxonomy}

Adult specimens were identified using current taxonomic literature (Allsopp 1990; Baehr 1984, 1986a,b, 1992, 1993, 1994, 1997, 2004, 2005; Bänninger 1940; Britton 1957, 1980, 1986, 1987, 1988, 1990, 2000; Freitag 1979; Giachino 2003; Howden 1974, 1976, 1979, 1984, 1985, 1992, 1993; Howden and Cooper 1977; Hudson 2000; Matthews 1972, 1974, 1980, 1984, 1987, 1992, 1993, 1998; Matthews and Bouchard 2008; Matthews and Stebnicka 1986; Matthews and Weir 2002; Moore 1963, 1965; Paulian 1980; RoigJuñent 2000; Stebnicka and Howden 1995, 1996, 1997; Storey 1991) and comparisons to accessible type specimens were made. Nomenclature and taxonomy follow Cassis and Weir (2002a,b,c,d, 2002e), Houston and Weir (2002), Matthews and Bouchard (2007) and Moore, Weir and Pyke (1987, 2007). A morphospecies approach was adopted where confidently assigning specimens to known described or undescribed taxa was difficult and available literature insufficient (Harvey et al. 2000). Taxa of Bolboceratidae, Carabidae, Hybosoridae, Scarabaeidae and Tenebrionidae identified in the survey are presented in Appendix 2. Representative series encompassing the distributional variation in the taxa (herein termed 'species') are lodged 
at the Western Australian Museum (WAM) and Australian National Insect Collection (ANIC). The remaining invertebrate material was sorted to order or family, lodged with the Western Australian Museum but not analysed due to time and personnel constraints.

\section{Analysis}

Patterns in the Pilbara beetle matrix (presence and absence of species at quadrats) were explored using the computer package PATN (Belbin 1995). To minimise distortions in the analysis from undersampling due to major disturbances (cyclonic events, inundation, fire), affected quadrats were removed from the matrix. Likewise, species recorded at only one quadrat (irrespective of numerical abundance at that quadrat) and quadrats with beetle assemblages comprising one species (herein referred to as 'singletons') were also removed prior to quadratlevel analyses. Next, overall sampling effectiveness for beetle species was assessed using both the Chao2 and incidence-based (ICE) estimators in the EstimateS software (Colwell 2006).

The Czekanowski association measure was used to compare quadrats according to similarities in their species composition, and the Two-Step association measure was used to compare species on the basis of their co-occurrences at quadrats. Dendrograms were constructed from these association matrices using an unweighted pair group arithmetic averaging (UPGMA) hierarchical clustering strategy (Sneath and Sokal 1973; Belbin 1995), and the reordered data were displayed as a two-way table. Structure in the quadrat dendrogram was assessed in terms of the quadrat descriptions, and statistically in terms of the substrate and climatic attributes measured for the quadrats using univariate Kruskal-Wallis tests.

The relationship between assemblage structure and substrate was investigated further by analysing the quadrat resemblance matrix using the ANOSIM routine in PRIMER v6 (Clarke and Gorley 2006). A single ('gestalt') substrate factor was used for this test, in which each quadrat was assigned to one of three states - predominantly rocky, sandy or clayey (see McKenzie et al. 2009).

Quadrats were pseudo-replicated between survey cells and within individual cells for the more extensive geomorphic units. This allowed each survey cell to be treated as a single landscape-scale relevé. Thus, broad biogeographical patterns could be assessed by classifying survey cells according to similarities in their overall species composition. Singleton species were restored to the matrix for this analysis, but not the under-sampled quadrats. The resulting classification structure was examined statistically in terms of the average environmental attributes of the survey cell's component quadrats using Kruskal-Wallis sample tests.

\section{RESULTS}

\section{The Fauna}

A total of 429 species representing 126 genera of ground-dwelling beetles from the Bolboceratidae, Carabidae, Hybosoridae, Scarabaeidae and Tenebrionidae were recorded from the quadrats sampled during the survey (Appendix 2; 427 species were used in the analyses, Megacephala nr. intermedia and Megacephala nr. karratha were collected only from excluded quadrat DRC12, and therefore not included). The Bolboceratidae were

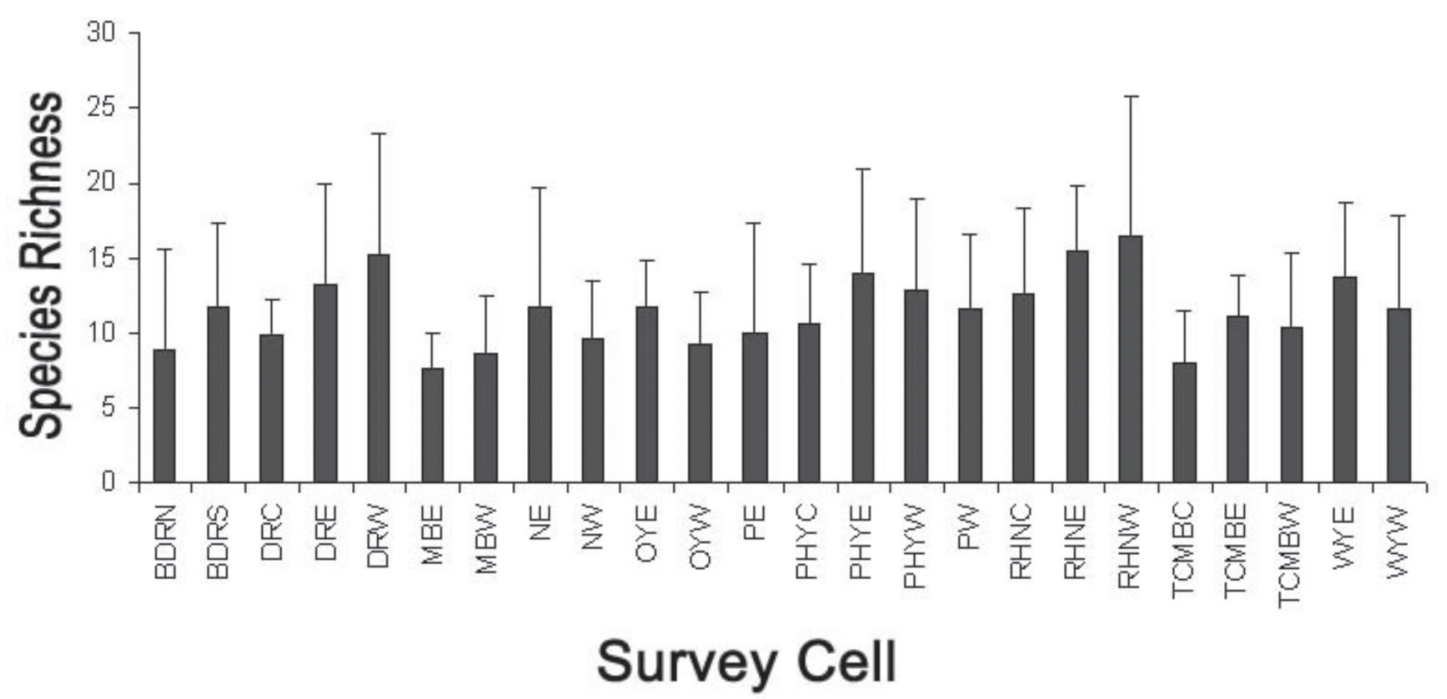

Figure 4 Average species richness for individual survey cells (cells listed in alphabetical order). Number of sampled quadrats within each cell: 9-NW; 11-DRC, MBE, OYE, PHYC; 12-PE, RHNE, TCMBC, WYW; 13-BDRN, BDRS, DRE, DRW, MBW, NE, OYW, PW, PHYE, PHYW, RHNC, RHNW, TCMBE, TCMBW, WYE. 


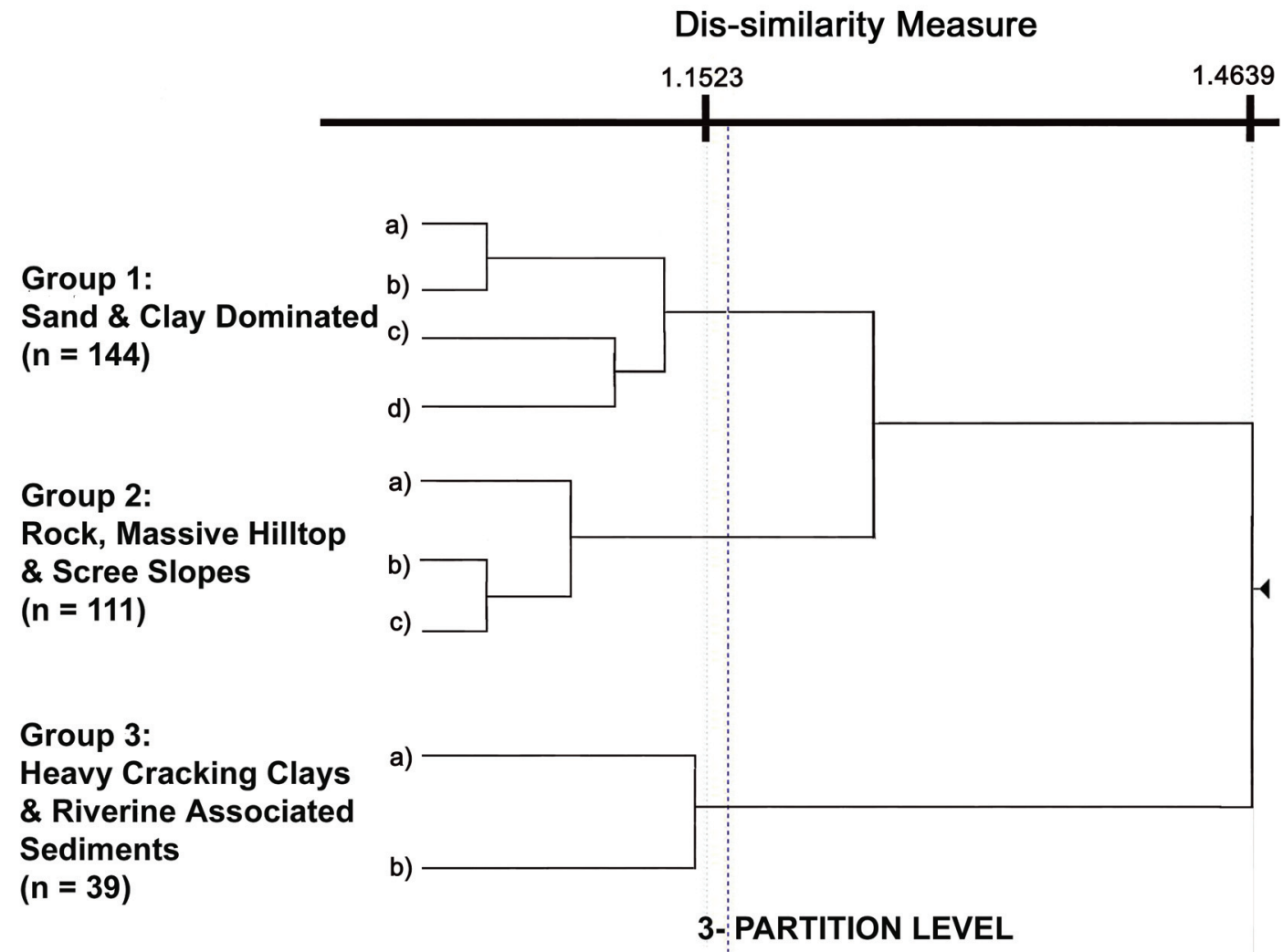

Figure 5 Quadrats classified according to similarities in species composition. Dendrogram structure displayed to the 3-group level. See text for detailed explanation of sub-groups.

represented by 22 species in six genera from the Bolboceratinae. The Carabidae were represented by 223 species in 61 genera within 21 subfamilies. Six species from three genera represented the Hybosoridae and 95 species in 25 genera represented four subfamilies of the Scarabaeidae. The six Tenebrionid subfamilies recorded were represented by 80 species in 32 genera.

Species richness ranged from 1 to 36 species per quadrat (TCMBC06, 1 Carabidae only; DRW02, 16 Carabidae, 10 Tenebrionidae, 10 Scarabaeidae respectively) with an average of $11.6 \pm 5.9$ species S.D. ( $\mathrm{n}=294$ quadrats). Within individual survey cells, average species richness per quadrat ranged between 7.6 (MBE) and 16.4 (RHNW) respectively, with no significant difference between cells established in either year (Figure 4).

One hundred and forty-three species, or 33\% of the fauna, were recorded at one quadrat only. All five families were represented by singletons in this study, and comprised: Bolboceratidae 36\% (8 species), Carabidae 32\% (72 species), Hybosoridae $33 \%$ (2 species), Scarabaeidae $46 \%$ (45 species) and Tenebrionidae $22 \%$ (17 species). Ninety-five quadrats were found to have at least one singleton species with the most singletons occurring at quadrat DRW02 (5 species). The majority of singletons were recorded from cells DRE (13 species), DRW (13), NE (12), PHYE (10) and RHNE (10).

ICE and Chao2 procedures in EstimateS produced estimates of 585 and 596 species, respectively, for the 294 quadrats. Therefore, the trapping program revealed $72-73 \%$ of total estimated richness across the range of Pilbara environments sampled. The accumulation curves had flattening-off but were not yet asymptotic; over the final 20 quadrats sampled, 0.5 additional species were being added per quadrat.

\section{Quadrat composition}

Nine quadrats were under-sampled because they were inundated (DRC12 - tides, OYE12 - cyclonic flooding), burnt (MBE01; NW01, NW09, NW10) or inaccessible (MBE10, NW01, OYE08) during the sampling period, so were excluded from the analysis matrix along with species that occurred at only one quadrat. The final matrix comprised 321 species and 294 quadrats. When the quadrats were classified according to similarities in their species compositions, the resulting quadrat dendrogram structure reflected differences in soil and landform attributes (Figure 5).

Group 1 comprised sand- and clay-dominated quadrats. Four internal partitions were discerned: 
Slope $(K W=112.8, P=0.0001)$

$\begin{array}{clc}\text { Group } & \text { Mean } & \mathrm{N} \\ 1 & 1.03 & 144 \\ 2 & 3.95 & 111 \\ 3 & 0.58 & 39\end{array}$

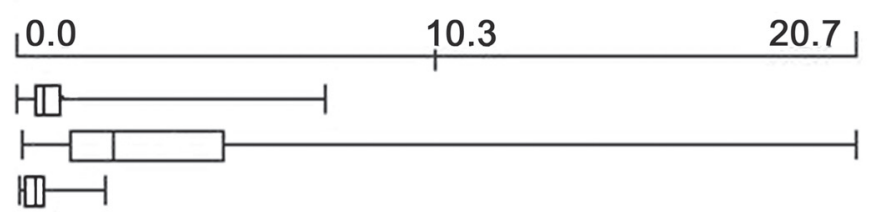

$\begin{array}{ccc}\text { Group } & \text { Mean } & \mathrm{N} \\ 1 & 33.8 & 144 \\ 2 & 15.8 & 111 \\ 3 & 59.0 & 39\end{array}$

Depth $(K W=87.8, \quad P=0.0001)$

$\begin{array}{cll}\text { Group } & \text { Mean } & \mathrm{N} \\ 1 & 3.57 & 144 \\ 2 & 6.46 & 111 \\ 3 & 13.5 & 39\end{array}$

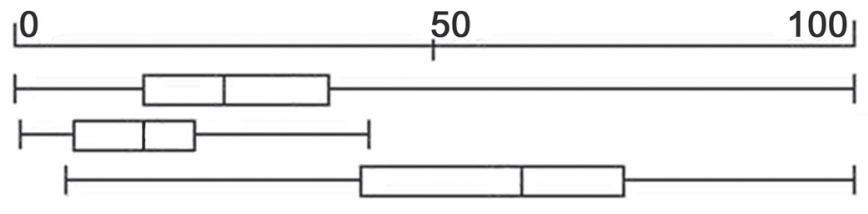

exCa $(\mathrm{KW}=86.9, \quad P=0.0001)$

$0.3 \quad 20.1 \quad 40.0$

Figure 6 Statistical assessment of the three-group classification (Figure 5) according to the slope $\left({ }^{\circ}\right.$ above the horizontal), depth (cm), exchangeable Calcium (exCa; me\%), exchangeable Potassium (exK; me \%), and sand (\%) values for the quadrats. Bars indicate $95 \%$ confidence intervals around the mean; Group = classification group number in Figure 5; $\mathrm{N}=$ number of survey cells in each classification group.

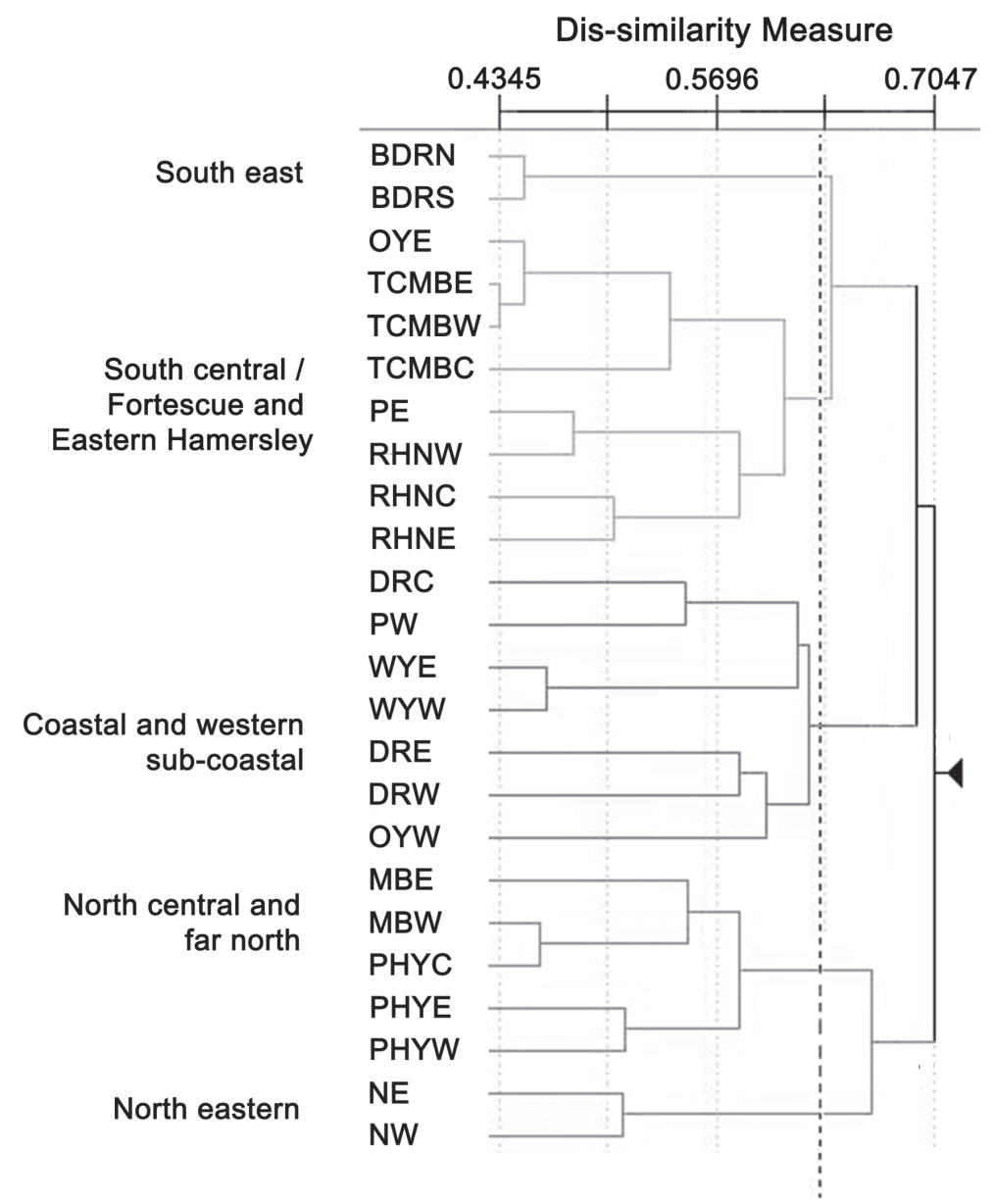

Figure 7 Survey cells classified according to similarities in species composition. Dendrogram structure displayed at the 5-group level. 


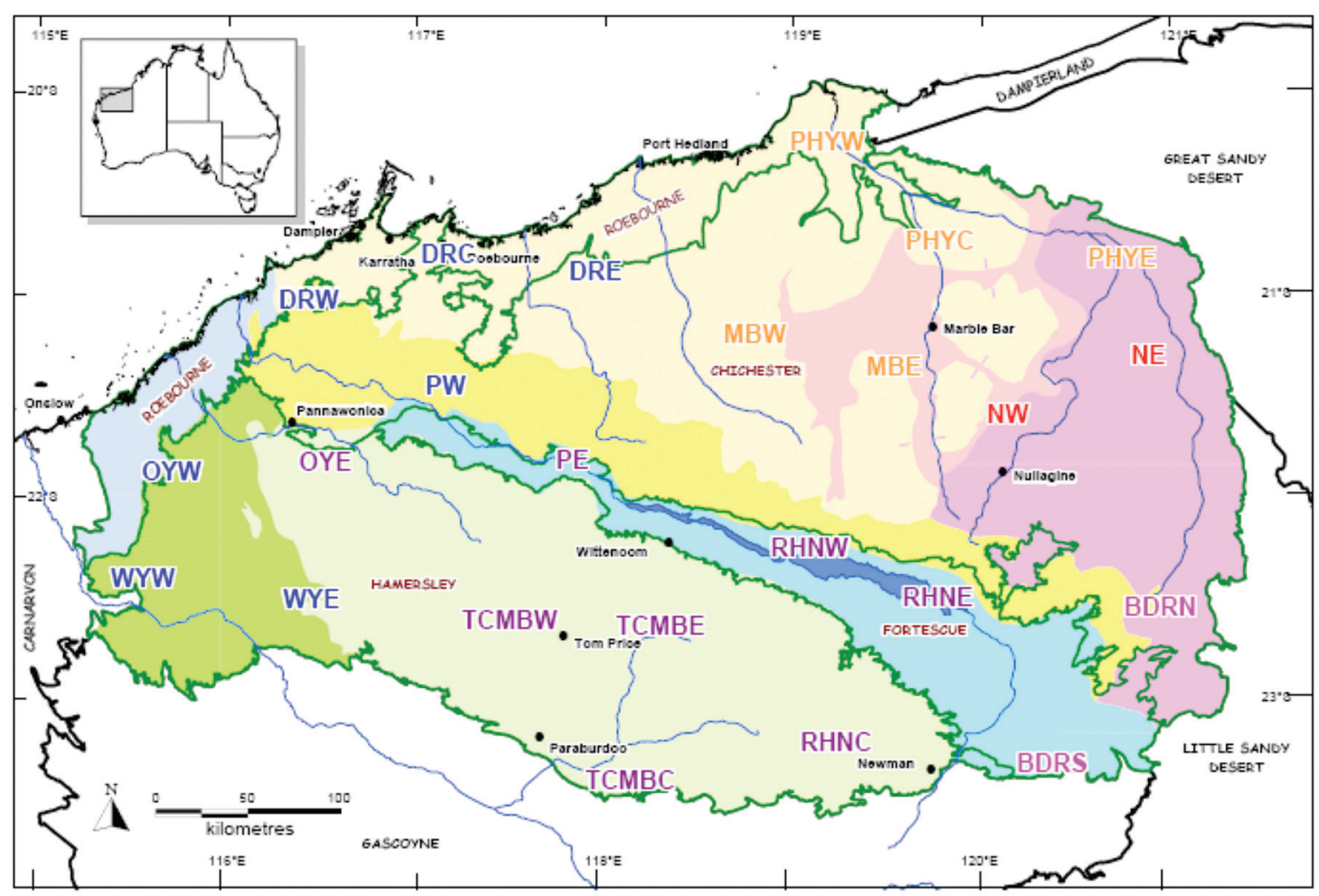

Figure 8 Map of the Pilbara showing a) survey cells colour coded to their clustering position in the survey cell dendrogram (Figure 7): Group 1 (South-east) - pink; Group 2 (South central \& Fortescue/ Eastern Hamersley) - purple; Group 3 (Coastal \& western sub-coastal) - blue; Group 4 (North central \& far north) - orange; Group 5 (North eastern) - red. b) boundaries of the four IBRA subregions outlined in green, and c) Beard's (1975) eight subregions: Oakover Valley (dark pink), central Gorge Range (pale pink), Abydos Plain (beige), Chichester Plateau (yellow), Fortescue (pale blue), Hamersley Range (pale green), Stuart Hills (green), Onslow Plain (mauve), d) major rivers (dark blue) and towns.

a) beach and desert sand dunes; b) gritty sands, deep clays with stony profiles, clay pans and claysilts; c) deep clays with stony profiles and surface strew of fragments and some stony uplands; and, d) sand dunes and deep clay profiles with outcropping of varying amounts rock or boulders. Group 2 comprised quadrats with massive rocks of hilltops and steep scree slopes, along with stony uplands and calcrete or opaline hills. Three internal partitions were identified: a) massive hilltop and scree slopes from the Chichester Range, Oakover valley and Stuart Hills; b) deep clayey profiles with surface strew and/or stony profiles, with Onslow Plains quadrats clustering together; c) massive hilltops and steep scree slopes primarily from coastal regions and the Stuart Hills. Group 3 comprised heavy cracking clays and riverineassociated muds and clays; its two internal partitions separated a) heavy cracking clays and saline muds from b) riverine levees with alluvial clay-silt, river sand beds or grit-sand river beds.

In combination, slope, soil profile and depth separated all three groups in the partition structure (Figure 6), although three other soil attributes showed a pattern of statistical differences similar to exchangeable calcium (exCa): exchangeable potassium $(\mathrm{KW}=65.4, P=0.0001)$, sand $(\mathrm{KW}=54.5$, $P=0.0001)$ and exchangeable magnesium (exMg).

An ANOSIM test revealed significant differences in beetle assemblage composition when quadrats were assigned among three categories (predominantly rocky, sandy, or clayey; global $\mathrm{R}=$ $0.20, P<0.001$ ). All possible pairwise comparisons were significant at $P<0.001$, with an R statistic of 0.27 for rocky versus sandy, 0.20 for rocky versus clayey and 0.12 for sandy versus clayey. Despite differences in the beetle assemblage composition, individual families were not restricted to any one quadrat category (i.e. rocky, sandy or clayey; Appendix 3).

\section{Biogeographical regionalisation}

The landscape-scale matrix comprised 24 survey cells and 427 species. The dendrogram derived from classifying the survey cells according to their total species composition (Figure 7) revealed strong geographically localised patterns down to the five partition level at least (Figure 8). The combination of two attributes statistically separated all five 
partitions: longitude and elevation (Figure 9). Thirty-six percent of species were recorded in only one survey cell and $46 \%$ were restricted to a single dendrogram partition as mapped in Figure 8.

\section{DISCUSSION}

\section{The fauna}

The Pilbara assemblages of Bolboceratidae, Carabidae, Hybosoridae, Scarabaeidae and Tenebrionidae were species-rich, with a total of 429 species identified in the present survey. Across these families, $68 \%$ could not be assigned to currently recognised species. It is likely that many more species are yet to be discovered, particularly in habitats and substrates not sampled during the present survey. The proportion of unrecognised taxa differed considerably between families, reflecting the groups currently requiring taxonomic revisions. Of the Carabids, 140 taxa could not be assigned to recognised species. The majority of these were in the Scaritine genera Carenum and Clivina (28 of 33 and 14 of 16 species, respectively). The Melolonthine genus Heteronyx accounted for 20 of the 98 unassigned species within the Scarabaeidae, and only one Tenebrionid species could be attributed to a known species. At the generic level, however, assignment of taxa was extremely high with all Bolboceratidae, Hybosoridae and Scarabaeidae assigned to recognised genera, while three Carabidae and ten Tenebrionidae taxa could not be attributed to recognised genera. Of these Tenebrionidae, four were within the Alleculinae, three in the Lagriinae, two representing the Palorinae and one taxon could not currently be assigned to a subfamily. We infer that the majority of the genera within these five beetle families present in the region have been described but it is expected that many more species remain to be discovered, particularly in habitats and substrates not sampled during the present survey.

Singleton species or those occurring at few quadrats might be rare, volant, 'tourist species' (passing through the area), only able to move short distances, or might have short adult reproductive phases so that opportunities to fall into pitfall traps are limited (Davies and Margules 2000). These species can provide an important percentage or portion of the total species richness of an area (Gaston 1996, cited in Lobo et al. 2004). If they are excluded from analyses such as predictive modelling, then differences between localities are reduced, limiting the model's predictive power (Lobo et al. 2004). However, to reduce type II errors in species composition analyses, singleton species must be removed. But the singleton species must be considered during interpretation of the results when reconstructing biogeographic histories of taxa and forming conservation decisions for areas and species (Lumaret and Lobo 1996). Singleton species constituted $33 \%$ of the fauna recorded during the Pilbara survey. The majority were either collected from areas near the edge of the region or were associated with the Fortescue subregion. The former may have their distributions centred elsewhere, while singletons from the Fortescue

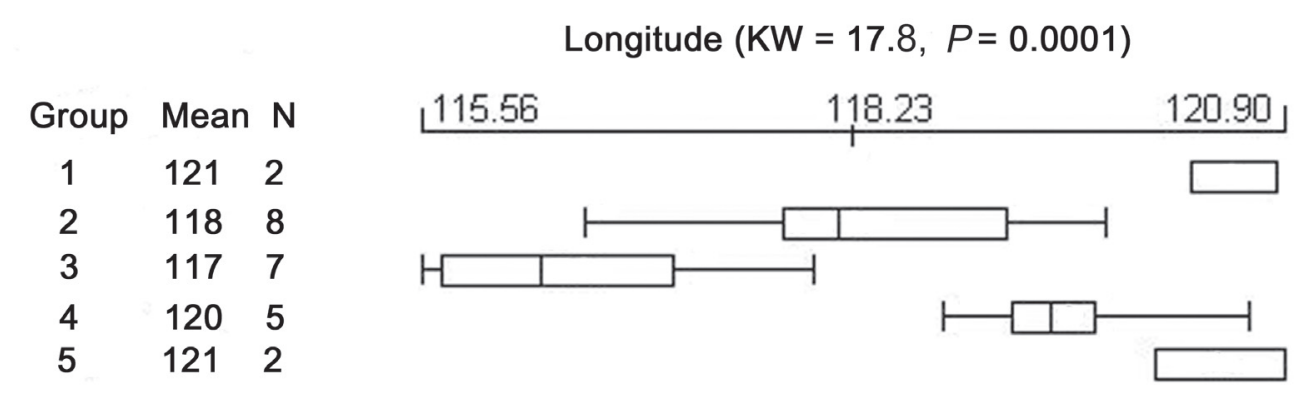

$\begin{array}{ccc}\text { Group } & \text { Mean } & \text { N } \\ 1 & 500 & 2 \\ 2 & 498 & 8 \\ 3 & 118 & 7 \\ 4 & 150 & 5 \\ 5 & 321 & 2\end{array}$

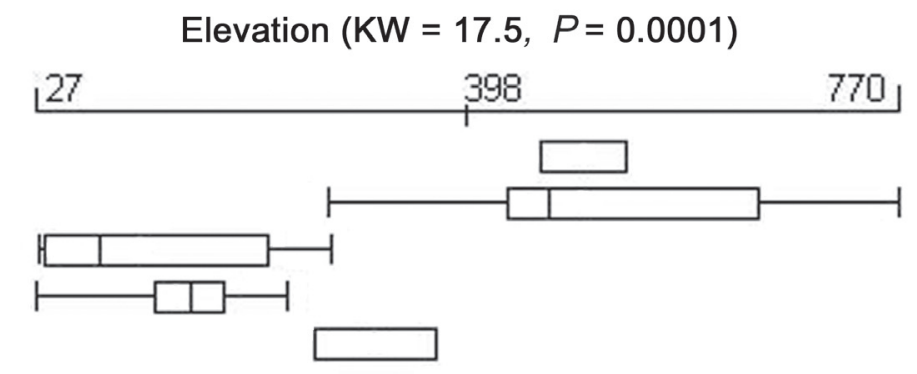

Figure 9 Environmental attributes that best separated the five survey cell groups defined in Figure 7. Bars indicate $95 \%$ confidence intervals around the mean; Group = classification group number in Figure 7; $\mathrm{N}=$ number of survey cells in each classification group. 
subregion may be restricted to habitats that are rare elsewhere in the region.

There is no doubt that under-sampling influenced the analytical result. The $72 \%$ sampling effectiveness value (from EstimateS) may reflect the quick response of the highly mobile, volant beetle species to local fluctuations in environmental productivity. There were pronounced fluctuations in rainfall across the study area during the survey period (quadrat-to-quadrat, season-to-season and year-to-year; see McKenzie et al. 2009).

Australian Bolboceratidae exhibit high generic endemicity and occur mainly along coastal regions and to a lesser extent in the dry interior (Howden 1981). There is little ecological information for Australian species but associations with sandy habitats for larger species have been recorded (Howden 1981). Twenty-two Bolboceratid species in six genera were collected during the survey. Six species of Austrolobolbus were usually found at either rocky or clay-based quadrats. Austrolobolbus pseudobscurius, A. subretusus and A. impressicollis were found in discrete populations across the survey region. Five of the 10 Blackburnium species were recorded only from sand dune quadrats of the region's eastern periphery and one on various landforms there, suggesting a wider range in the sandy deserts extending eastwards from the Pilbara. Bolboleaus truncatus and B. trifoveicollis were distributed more widely, having several discrete populations on deep clay or rocky quadrats in most survey cells.

Twenty-one Carabid subfamilies were collected in the survey. The Amblystominae were represented by 13 specimens from three species. Three genera of Bembidinae were collected in the survey; the most diverse was Tachys with 11 species, including Tachys convexicollis present at 11 sites. Our collection of Sarothrocrepis benefice (Cyclosominae) was a minor range extension for this wide-ranging species. Range extensions were recorded for three species of Gnathaphanus (Harpalinae): G. froggatti, G. melbournensis, and G. multipunctatus. Two undesignated Helluo (Helluoninae) species were collected well outside the genus's known range in the Murray-Darling basin. Nototarus (Lebiinae) was represented by three described and 16 undescribed species. The related genus Anomotarus was represented by three dry-country species: $A$. nitidior, a little-known northern Australian 'forest litter' dwelling species (Baehr 2005) collected during the survey only from MBW07, A. nubilus, and $A$. umbratus, a halophile inhabiting sand flats (Baehr 2005). Gestroania amplipennis (Odacanthinae) was collected only from WYE13, and may be on the northern limits of its otherwise south-western distribution. Renneria kamouni (Odacanthinae) was recorded from 10 sites, representing a significant range extension south-westward from far north Kimberley and adjacent Northern Territory. Undetermined species were recorded for the Pterostichinae genera Cratogaster, Darodilia, Loxandrus, Platycoelus and Rhytisternus. Significant range extensions were recorded for Loxandrus laevigatus, L. micantior and Platycoelus melliei. Nine genera (including one undesignated genus) represented the Scaritinae in the survey. Twentyeight of the 33 Carenum species were unplaced, and Clivina was represented by 14 unplaced and 2 described species. Six species from four genera represented the Zuphinae: Acrogenys and Zuphium were each represented by two species. The record of Acrogenys centralis (Zuphinae) at NE13 represents a major range extension from the only known locality, Amata, Musgrave Range, South Australia. Likewise, the record of Zuphium flavum (Zuphinae) at TCMBW04 represents a range extension of 2000 $\mathrm{km}$ from the previously known distribution in the Lake Eyre Basin, South Australia.

The Hybosoridae have undergone extensive species-level radiation in Australia, with 40 species in 3 genera, compared to 183 species in 31 genera worldwide. Present across mainland Australia, the richest fauna is found in the tropical northern regions. Six species, representing all three Australian Hybosorid genera, were recorded during the Pilbara survey. They were often found on rocky quadrats, usually with massive boulders and steep scree slopes, or on calcrete or opaline hills and mesas, but were rarely collected from quadrats with predominantly sand or clay profiles. Three undesignated Antiochrus species were centred on (but not limited to) quadrats scattered around the periphery of the survey region. Liparochrus carnei and L. rufus were collected within their known ranges. Phaeochrous australicus exhibited several discrete populations occurring in adjacent quadrats across several survey cells.

Ninety-five species within 25 genera represented four subfamilies of the Scarabaeidae. Nine species within three genera of the Aphodiinae had distributions centred on (but not limited to) the survey cells RHNC, RHNE and RHNW in the south-eastern Pilbara. The Dynastinae were represented by six species in four genera; notably, Cryptodus caviceps was recorded at several coastal quadrats with deep clay profiles or rocky landforms, and Teinogenys aurilegulus was usually recorded at Fortescue Valley quadrats with deep clay profiles or rocky landforms. Fifty-six species across 11 genera represented the Melolonthinae. Six genera were represented by single species (one species at two quadrats, the rest at one quadrat). Lepidiota squamulata occurred in discrete populations at adjacent quadrats across several 
survey cells. Twenty-nine species of Heteronyx were collected, most of which were recorded widely across the survey region. Liparetrus and Gnaphalopoda, with 11 and 6 species respectively, were also recorded at widely scattered quadrats across the region. The Scarabaeinae were represented by 26 species in seven genera; of these, four genera had single species. Fourteen Onthophagus species were recorded in the survey, seven of which were restricted to ten or fewer quadrats. The other seven were widely distributed across the region. Of the determined species of Scarabaeinae, records within the survey corresponded with generalised known or hypothesised distributions (Matthews 1972, 1974) with a few minor range extensions. The native Scarabaeinae recorded in the Pilbara prior to this survey were six Onthophagus species; of these, only O. murchisoni was not recorded in this survey.

The Tenebrionidae were represented by 80 species within 32 genera across seven subfamilies. Eleven species across five genera of the Alleculinae were recorded, including four undesignated species in two tentative genera. Metiste sp. 1 was the only widespread Alleculine recorded in the survey. The Coelometopinae was represented by Hypaulax orcus, widely distributed and absent only from PHYW and TCMBW, and Oectosis sp. 1, present only at DRW02. Five Isopteron species (Lagriinae) exhibited discrete distributions across adjacent survey cells. The three unplaced Lagriinae and two unplaced Palorinae taxa were widely distributed across several rocky habitat quadrats. The myrmecophilous genera Thorictosoma and Wattiana (Pimeliinae), represented by six and one species respectively, were recorded at scattered quadrats across the survey region. The most diverse subfamily represented in the survey was the Tenebrioninae, with 45 species in 14 genera across three tribes. The five species of Chalcopteroides (Amarygmini) were widely distributed, with three species each collected at one quadrat only. The Opatrini was represented by two widespread genera, Gonocephalum, Mesomorphus; and two genera previously collected on littoral sands (Matthews and Bouchard 2008), Caedius and Sobas; all were recorded in scattered quadrats across the survey region. Twenty-four species across eight genera represented the Heleini. Three species of the highly localised subterranean Dysarchus (Matthews and Bouchard 2008) were recorded at several coastal quadrats with either rocky, stony or granitoid profiles. The most commonly encountered genus was Boreosaragus, with three undetermined species, with Boreosaragus sp. 1 present at 200 quadrats.

All five families sampled, therefore, have significant species richness in the Pilbara, and all include a range of taxa that appear to have restricted distributions.

\section{Compositional patterns}

At the quadrat or local-scale, beetle composition was correlated with the land substrate attributes slope, soil depth, and exchangeable calcium (along with exchangeable potassium and sand). Heavy cracking clays, saline muds and riverine-associated muds formed a distinct group in the quadrat analysis. A distinctive suite of species was recorded but was not necessarily limited to these quadrats. Most of the common or widely distributed species were absent from this quadrat group.

At the biogeographic regional scale, strongly localised geographical patterns emerged from the survey cell analysis. Longitude and elevation showed strong correlations with compositional turnover, and the 5-group level dendrogram partitions reflected the physio-geographical subregions described by Beard (1975) (Figure 7).

It is difficult to place our findings into a wider context; an extensive literature search has failed to find comparable studies examining environmental attributes and beetle assemblage turnover. However, when the gross morphology and general ecology of the various families are taken into account, our findings are logical. All five families are ground-dwelling terrestrial beetles, and within each family there exist varying fossorial abilities and adaptations to different soil and terrain types.

Therefore, to preserve the diversity of these families in the Pilbara region, reserves encompassing a range of land and soil substrate attributes (at the localised micro-scale) are required in each of the subregions as part of a comprehensive conservation reserve system.

Little is known about regions of endemism for Australian beetles. Matthews and Bouchard (2008) described 10 areas of endemism for Tenebrionids, with the closest to the Pilbara being the 'Murchison'. These regions may have acted as historical refugial areas, with fauna repeatedly retreating to them during times of aridity or marine incursions. Whether or not the Pilbara has acted in the same manner is unknown, but the relatively high number of local endemics (33\%) found in this survey suggests that the Pilbara may be an important and previously unrecognised refugial area with high endemism.

\section{CONCLUSIONS}

We noted that the resident Pilbara assemblages of Bolboceratids, Carabids, Hybosorids, Scarabaeids and Tenebrionids are species-rich, but dominated by few highly abundant species. Assemblages comprise a component of common or widely distributed species (often with large numbers of individuals appearing to exhibit wide morphological variability within and between 
quadrats), and components of species that occur at relatively few quadrats (each represented by a few specimens at any one quadrat). This could reflect actual species distributions, or be an artefact of highly variable multiple year-to-year population fluctuations influencing trapping success and/or deficiencies in the current taxonomic resolution.

Assemblage composition varied at the local and regional scales, reflecting landform (slope) and soil characteristics at the local scale and the physiogeographical subregions regionally.

It appears that localised evolutionary processes associated with limited mobility have resulted in a beetle fauna with a high proportion of stronglylocalised endemic forms. Detailed comparisons with neighbouring semi-arid areas such as the Great and Little Sandy Deserts, Ashburton and Northern Carnarvon Basin are required to clarify phylogenetic relationships between beetle taxa, their distributions, and to explore further the correlation of species composition with various land surface attributes that have emerged from our analysis.

\section{ACKNOWLEDGEMENTS}

Major funding for this project was provided by the WA Department of Environment and Conservation, with contributions from the Western Australian Museum, the Commonwealth Government (through the Natural Heritage Trust; NHT2) and Straits Resources. Substantial, inkind support was also provided by Rio Tinto Iron Ore, BHP Billiton Iron Ore and Kitchener Mining (Bamboo Creek Operation).

We gratefully acknowledge the numerous Pilbara pastoralists and Aboriginal communities for permission to access their leases and/or land. In particular, Robyn and Tony Richardson of Mt Florance Station provided free access to their camping ground for the survey site installation and sampling teams, and Rio Tinto Iron Ore provided access to subsidised housing for the first installation team while operating out of Karratha.

DEC Pilbara Region and National Park staff at Karratha and at Karijini and MillstreamChichester National Parks provided subsidised accommodation for pit-trap installation teams and sampling teams; Department of Water provided access to Tabletop Hill, Harding Dam and sites along the West Pilbara water supply pipeline. Rio Tinto Iron Ore and BHP Billiton Iron Ore are acknowledged for permission to enter their exploration leases and for granting access to their rail access roads.

We also thank B.J. Durrant, G. Owen, J. Dunlop, E. Ladhams and S. Danti for help in sorting samples; J. Angus and B. Hanich for help with specimen preparation; and M. Baehr for taxonomic expertise. N.L. McKenzie and A.H. Burbidge provided analytical advice. N.L. McKenzie and S. van Leeuwen selected the quadrats, J.K. Rolfe, R. Bromilow, P. Cullen, T. Farmer, D. Kamien, B. Muir, C. Parker, R. Whitlaw, J. Dunlop, A. Lang, W. Manson, J. Nolthenius and T. Smith installed the traps, and logistical support was provided by $\mathrm{S}$. van Leeuwen, R. Bromilow, M. Hughes and T. Smith.

\section{REFERENCES}

Abensperg-Traun, M., Smith, G.T., Arnold, G.W. and Steven, D.E. (1996). The effects of habitat fragmentation and livestock-grazing on animal communities in remnants of gimlet Eucalyptus salubris woodland in the Western Australian wheatbelt. I. Arthropods. Journal of Applied Ecology 33: 1281-1301.

Allsopp, P.G. (1990). Revision of the Systellopini (Coleoptera: Scarabaeidae: Melolonthinae). Invertebrate Taxonomy 3 (1989): 197-227.

Austin, A.D., Yeates, D.K., Cassis, G., Fletcher, M.J., La Salle, J.L., Lawrence, J.F., McQuillan, P.B., Mound, L.A., Bickel, D.J., Gullan, P.J., Hales, D.F. and Taylor, G.S. (2004). Insects 'Down Under' - diversity, endemism and evolution of the Australian insect fauna: examples from select orders. Australian Journal of Entomology 43: 216-234.

Baehr, M. (1984). Pogonus nigrescens sp. n. from north Queensland (Coleoptera: Carabidae). Journal of the Australian Entomological Society 23: 169-171.

Baehr, M. (1986a). Revision of the Australian Zuphiinae 6. The genus Planetes Macleay. Supplement to the other genera (Insecta, Coleoptera, Carabidae). Spixiana (Munich) 9: 151-168.

Baehr, M. (1986b). Revision of the Australian ground beetle genus Porocara Sloane (Coleoptera: Carabidae: Odacanthinae). Australian Journal of Zoology 34: 717-731.

Baehr, M. (1990). The carabid community living under the bark of Australian eucalypts (pp 3-11). In: Stork, N.E. (ed.), The role of ground beetles in ecological and environmental studies. Intercept Ltd: Andover, Hampshire, U.K.

Baehr, M. (1992). A new Acrogenys Macleay from Central Australia. Supplement to the revision of the Australian Zuphiinae (Insecta, Coleoptera, Carabidae). Spixiana 15: 75-80.

Baehr, M. (1993). New species and new records of the genus Sphallomorpha Westwood from Australia. Supplement to the revision of the Pseudomorphinae of the Australian region I. Spixiana 16: 25-42.

Baehr, M. (1994). New species and new records of the genus Sphallomorpha Westwood from Australia and New Guinea. $3^{\text {rd }}$ Supplement to the revision of the Pseudomorphinae of the Australian region I. Spixiana 17: 215-235.

Baehr, M. (1997). Two new species of the genus Pogonus Nicolae from Australia (Insecta, Coleoptera, Carabidae, Pogoninae). Spixiana 20: 1-6.

Baehr, M. (2004). The Amblytelini. A tribe of corticolous ground beetles from Australia. Taxonomy, phylogeny, 
biogeography. (Coleoptera: Carabidae: Psydrinae). Coleoptera 8: 1-286.

Baehr, M. (2005). The Australian species of the genus Anomotarus Chaudoir, subgenus Anomotarus s. str. (Insecta: Coleoptera: Carabidae: Lebiinae). Coleoptera 9: 11-107.

Bänninger, M. (1940). On Australian Pamborini, Ozaenini and Scaritini (Coleoptera: Carabidae). Novitate Zoology 42: 203-213.

Beard, J.S. (1975). Vegetation survey of Western Australia: Pilbara. University of Western Australia Press: Nedlands, Australia.

Beard, J.S. (1990). Plant life of Western Australia. Kangaroo Press: Kenthurst, Australia.

Beard, J.S., Chapman, A.R. and Gioia, P. (2000). Species richness and endemism in the Western Australian flora. Journal of Biogeography 27: 1257-1268.

Belbin, L. (1995). PATN technical reference. CSIRO Division of Wildlife and Ecology: Canberra, Australia.

Bouchard, P. and Yeates, D.K. (2001). Phylogenetic relationships of the Australasian Coelometopini (Coleoptera: Tenebrionidae); a quantitative cladistic analysis with a review of biology. Organisms, Diversity and Evolution 1: 17-43.

Britton, E.B. (1957). A revision of the Australian chafers (Coleoptera: Scarabaeidae: Melolonthinae). Vol. 1. British Museum (Natural History): London, U.K.

Britton, E.B. (1980). A revision of the Australian chafers (Coleoptera: Scarabaeidae: Melolonthinae). Vol. 3. Tribe Liparetrini genus Liparetrus. Australian Journal of Zoology, Supplementary Series 76: 1-209.

Britton, E.B. (1986). A revision of the Australian chafers (Coleoptera: Scarabaeidae: Melolonthinae). Vol. 4. Tribe Liparetrini: Genus Colpochila. Australian Journal of Zoology, Supplementary Series 118: 1-135.

Britton, E.B. (1987). A revision of the Australian chafers (Coleoptera: Scarabaeidae: Melolonthinae). Vol. 5. Tribes Scitalini and Comophorini. Invertebrate Taxonomy 1: 685-799.

Britton, E.B. (1988). Synopsis of the genera of Australian Heteronycini (Coleoptera: Scarabaeidae: Melolonthinae). Journal of the Australian Entomological Society 27: 27-36.

Britton, E.B. (1990). A synopsis of the genera of Liparetrini (Coleoptera: Scarabaeidae: Melolonthinae). Invertebrate Taxonomy 4: 159-195.

Britton, E.B. (2000). A review of Heteronyx Guérin-Méneville (Coleoptera: Scarabaeidae: Melolonthinae). Invertebrate Taxonomy 14: 465-589.

Cassis, G. and Weir, T.A.; updated by Andrew A. Calder, CSIRO Entomology, Canberra (Dec 2002a). Hybosoridae. Australian faunal directory. Australian Biological Resources Study: Canberra, Australia. [Accessed 21 October 2008. http://www.environment.gov.au/ biodiversity/abrs/online-resources/fauna/afd/index. $\mathrm{html}]$

Cassis, G. and Weir, T.A.; updated by Andrew A. Calder, CSIRO Entomology, Canberra (Dec 2002b). Bolboceratidae. Australian faunal directory. Australian Biological Resources Study: Canberra, Australia. [Accessed 21 October 2008. http://www.environment. gov.au/biodiversity/abrs/online-resources/fauna/afd/ index.html]
Cassis, G. and Weir, T.A.; updated by Andrew A. Calder, CSIRO Entomology, Canberra (Dec 2002c). Aphodiinae. Australian faunal directory. Australian Biological Resources Study: Canberra, Australia. [Accessed 21 October 2008. http://www.environment.gov.au/ biodiversity/abrs/online-resources/fauna/afd/index. html]

Cassis, G. and Weir, T.A.; updated by Andrew A. Calder, CSIRO Entomology, Canberra (Dec 2002d). Dynastinae. Australian faunal directory. Australian Biological Resources Study, Canberra, Australia. [Accessed 21 October 2008. http://www.environment.gov.au/ biodiversity/abrs/online-resources/fauna/afd/index. html]

Cassis, G. and Weir, T.A.; updated by Andrew A. Calder, CSIRO Entomology, Canberra (Dec 2002e). Scarabaeinae. Australian faunal directory. Australian Biological Resources Study: Canberra, Australia. [Accessed 21 October 2008. http://www.environment.gov.au/ biodiversity/abrs/online-resources/fauna/afd/index. html]

Clarke, K.R. and Gorley, R.N. (2006). PRIMER v6: user manual/tutorial. PRIMER-E Ltd: Plymouth, U.K.

Colwell, R.K. (2006). EstimateS. Statistical estimation of species richness and shared species from samples Version 8.0. http:/ /viceroy.eeb.uconn.edu/estimates.

Cowling, R.M. and Lamont, B.B. (1998). On the nature of Gondwanan species flocks: diversity of Proteaceae in mediterranean South-western Australia and South Africa. Australian Journal of Botany 46: 335-355.

Davies, K.F. and Margules, C.R. (2000). The beetles at Wog Wog: a contribution of Coleoptera systematics to an ecological field experiment. Invertebrate Taxonomy 14: 953-956.

Environment Australia (2008). Revision of the Interim Biogeographic Regionalisation for Australia (IBRA) and development of version 6.1. National Reserves System. Department of Environment, Water, Heritage and the Arts: Canberra, Australia. [online: http:// www.environment.gov.au/parks/nrs/science/ bioregionframework/ibra/index.html]

Freitag, R. (1979). Reclassification, phylogeny and zoogeography of the Australian species of Cicindela (Coleoptera: Cicindelidae). Australian Journal of Zoology, Supplementary Series 66: 1-99.

Giachino, P.M. (2003). The genus Pheropsophus Solier, 1833 in Australia (Coleoptera, Carabidae) (pp 29-64). In: Daccordi, M. and Giachino, P.M. (eds), Results of the zoological missions to Australia of the Regional Museum of Natural Sciences of Turin Italy. I. - Monografie Museo Regionale di Scienze Naturali Torino, 35.

Gibson, L.A. and New, T.R. (2007). Characterising insect diversity on Australia's remnant native grasslands: ants (Hymenoptera: Formicidae) and beetles (Coleoptera) at Craigieburn Grasslands Reserve, Victoria Journal of Insect Conservation 11: 409-413.

Grimaldi, D. and Engel, M.S. (2005). Evolution of the insects. Cambridge University Press: New York, USA.

Harvey, M.S., Sampey, A., West, P.L.J. and Waldock, J.M. (2000). Araneomorph spiders from the southern Carnarvon Basin, Western Australia: a consideration of regional biogeographic relationships. Records of the Western Australian Museum, Supplement 61: 295-320. 
Harvey, M.S., Waldock, J.M., Guthrie, N.A., Durrant, B.J. and McKenzie, N.L. (2004). Patterns in the composition in ground dwelling araneomorph spider communities in the Western Australian wheatbelt. Records of the Western Australian Museum, Supplement 67: 257-292.

Hopper, S.D., Harvey, M.S., Chappill, J.A., Main, A.R. and Main, B.Y. (1996). The Western Australian biota as Gondwanan heritage - a review (pp 1-46). In: Hopper, S.D., Chappill, J.A., Harvey, M.S. and George, A.S. (eds), Gondwanan heritage: past, present and future of the Western Australian biota. Surrey Beatty \& Sons: Chipping Norton, Australia.

Houston, W.W.K. and Weir, T.A.; updated by Andrew A. Calder, CSIRO Entomology, Canberra, Australia, (Dec 2002). Melolonthinae. Australian faunal directory. Australian Biological Resources Study: Canberra, Australia. [Accessed 21 October 2008. http://www. environment.gov.au/biodiversity/abrs/onlineresources/fauna/afd/index.html]

Howden, H.F. (1974). A revision of the Australian genus Stenaspidius Westwood (Coleoptera, Scarabaeidae, Geotrupinae). Records of the South Australian Museum 17: 11-21.

Howden, H.F. (1976). A sixth species of Stenaspidius Westwood with a note on adult behaviour (Coleoptera: Scarabaeidae: Geotrupinae). Journal of the Australian Entomological Society 14: 439-441.

Howden, H.F. (1979). A revision of the Australian genus Blackburnium Boucomont (Coleoptera: Scarabaeidae: Geotrupinae). Australian Journal of Zoology, Supplementary Series 72: 1-88.

Howden, H.F. (1981). Zoogeography of some Australian Coleoptera as exemplified by the Scarabaeoidea (pp 1009-1035). In: Keast, A. (ed.), Ecological biogeography of Australia. W. Junk: The Hague, Netherlands.

Howden, H.F. (1984). The Australian Blackburnium harslettae-triceratops complex (Coleoptera: Scarabaeidae: Geotrupinae). Coleopterists' Bulletin 38: 190191.

Howden, H.F. (1985). A revision of the Australian beetle genera Bolboleaus Howden \& Cooper, Blackbolbus Howden \& Cooper, and Bolborhachium Boucomont (Scarabaeidae: Geotrupinae). Australian Journal of Zoology, Supplementary Series 111: 1-179.

Howden, H.F. (1992). A revision of the Australian beetle genera Eucanthus Westwood, Bolbobaineus Howden \& Cooper, Australobolbus Howden \& Cooper and Gilletinus Boucomont (Scarabaeidae: Geotrupinae). Invertebrate Taxonomy 6: 605-717.

Howden, H.F. (1993). New Bolboceratini from Western Australia (Coleoptera: Scarabaeidae: Geotrupinae). Journal of the Australian Entomological Society 32: 379-386.

Howden, H.F. and Cooper, J.B. (1977). The generic classification of the Bolboceratini of the Australian region, with descriptions of four new genera (Scarabaeidae: Geotrupinae). Australian Journal of Zoology, Supplementary Series 50: 1-50.

Hudson, P.J. (2000). A new flightless species of Pogonus Nicolai (Coleoptera: Carabidae) from Western Australia. Australian Journal of Entomology 39: 214-243.
Lawrence, J.L. and Britton, E.D. (1994). Australian beetles. Melbourne University Press: Carlton, Australia.

Lobo, J.M., Jay-Robert, P. and Lumaret, J.P. (2004). Modelling the species richness distributions for French Aphodiidae (Coleoptera, Scarabaeoidea). Ecography 27: 145-156.

Lumaret, J.P. and Lobo, J.M. (1996). Geographic distribution of endemic dung beetles (Coleoptera, Scarabaeidae) in the western Palaearctic region. Biodiversity Letters 3: 192-199.

Main. B.Y. (1996). Microcosmic biogeography: trapdoor spiders in a time warp at Durokoppin (pp 163-171). In: Hopper, S.D., Chappill, J.A., Harvey, M.S. and George, A.S. (eds), Gondwanan heritage: past, present and future of the Western Australian biota. Surrey Beatty \& Sons: Chipping Norton, Australia.

Main, B.Y. (2000). Habitat template for invertebrates on granite outcrops. Journal of the Royal Society of Western Australia 83: 139-167.

Majer, J.D. and Recher, H.F. (1988). Invertebrate communities on Western Australian eucalypts: a comparison of branch clipping and chemical knockdown procedures. Australian Journal of Ecology 13: $269-278$.

Matthews, E.G. (1972). A revision of the Scarabaeinae dung beetles of Australia I. Tribe Onthophagini. Australian Journal of Zoology, Supplementary Series 9: $1-330$.

Matthews, E.G. (1974). A revision of the Scarabaeinae dung beetles of Australia II. Tribe Scarabaeini. Australian Journal of Zoology, Supplementary Series 24: $1-211$

Matthews, E.G. (1980). A guide to the genera of beetles of South Australia. Part I. Archostemata and Adephaga. Special Educational Bulletin Series. South Australian Museum: Adelaide, Australia.

Matthews, E.G. (1984). A guide to the genera of beetles of South Australia. Part III. Polyphaga: Eucinetoidea, Dascilloidea and Scarabaeoidea. Special Educational Bulletin Series. South Australian Museum: Adelaide, Australia.

Matthews, E.G. (1987). A guide to the genera of beetles of South Australia. Part IV. Polyphaga: Tenebrionoidea. Special Educational Bulletin Series. South Australian Museum: Adelaide, Australia.

Matthews, E.G. (1992). Classification, relationships and distribution of the genera of Cyphaleini (Coleoptera: Tenebrionidae). Invertebrate Taxonomy 6: 437-522.

Matthews, E.G. (1993). Classification, relationships and distribution of the genera of Heleini (Coleoptera: Tenebrionidae). Invertebrate Taxonomy 7: 1025-1096.

Matthews, E.G. (1998). Classification, phylogeny and biogeography of the genera of Adeliini (Coleoptera: Tenebrionidae). Invertebrate Taxonomy 12: 685-824.

Matthews, E.G. and Bouchard, P.; updated by ABRS (2007). Tenebrionidae. Australian faunal directory. Australian Biological Resources Study: Canberra, Australia. [Accessed 21 October 2008. http://www. environment.gov.au/biodiversity/abrs / onlineresources/fauna/afd/index.html]

Matthews, E.G. and Bouchard, P. (2008). Tenebrionid beetles of Australia: descriptions of tribes; keys to genera; 
catalogue of species. Australian Biological Resources Study: Canberra, Australia.

Matthews, E.G. and Lawrence, J.F. (2005). New taxa, new synonymy and new generic records for Australian Tenebrionidae (Coleoptera). Annales Zoologici (Warszawa) 55: 531-547.

Matthews, E.G. and Stebnicka, Z. (1986). A review of Demarziella Balthasar, with a transfer from Aphodiinae to Scarabaeinae (Coleoptera: Scarabaeidae). Australian Journal of Zoology 34: 449-461.

Matthews, E.G. and Weir, T.A. (2002). Two new species of the genus Lepanus Balthasar from South Australia (Coleoptera: Scarabaeidae). Records of the South Australian Museum 35: 79-84.

May, J.E. and McKenzie, N.L. (eds) (2003). A biodiversity audit of Western Australia's biogeographical subregions in 2002. Western Australian Department of Conservation and Land Management: [Perth], Australia.

McKenzie, N.L., van Leeuwen, S. and Pinder, A.M. (2009), Introduction to the Pilbara biodiversity survey, 2002-2007. Records of the Western Australian Museum, Supplement 78: 3-89.

Michaels, K. (1999). Carabid beetle (Coleoptera: Carabidae) communities in Tasmania: classification for nature conservation. (pp 374-379). In: Ponder, W. and Lunney, D. (eds), The other 99\%: the conservation and biodiversity of invertebrates. Transactions of the Royal Zoological Society of New South Wales: Mosman, Australia.

Moore, B.P. (1963). Studies on Australian Carabidae (Coleoptera) 3. The Psydrinae. Transactions of the Royal Entomology Society of London 115: 277-290.

Moore, B.P. (1965). Studies on Australian Carabidae (Coleoptera) 4. the Pterostichinae. Transactions of the Royal Entomology Society of London 117: 1-32.

Moore, B.P., Weir, T.A. and Pyke, J.E. (1987). Rhysodidae and Carabidae (pp 20-320). In: Walton, D.W. (ed.), Zoological catalogue of Australia. Volume 4. Coleoptera: Archostemata, Myxophaga and Adephaga. Australian Government Publishing Service: Canberra, Australia.

Moore, B.P., Weir, T.A. and Pyke, J.E.; updated by Andrew A. Calder, CSIRO Entomology, Canberra, Australia, with extensive input from Martin Baehr (July 2007), Carabidae. Australian faunal directory. Australian Biological Resources Study: Canberra, Australia. [Accessed 21 October 2008. http://www. environment.gov.au/biodiversity/abrs/onlineresources/fauna/afd/index.html]

Naumann, I.D., Weir, T.A. and Edwards, E.D. (1991). Insects of Kimberley rainforests (pp 299-332). In: McKenzie, N.L., Johnston, R.B. and Kendrick, P.G. (eds), Kimberley rainforests. Surrey Beatty \& Sons: Chipping Norton, Australia.

New, T.R. (1998). The role of ground beetles (Coleoptera: Carabidae) in monitoring programmes in Australia. Annals of Zoologica Fennici 35: 163-171.

Paulian, R. (1980). Révision taxonomique des Liparochrus Erichson, genre Australo-Mélanésien de Coléoptères Hybosoridae, Scarabaeoidea. Annales de la Société Entomologique de France n.s. 16: 389-433.

Roig-Junent, S. (2000). The subtribes and genera of the tribe Broscini (Coleoptera: Carabidae): cladistic analysis, taxonomic treatment, and biogeographical considerations. Bulletin of the American Museum of Natural History 255: 1-90.

Ślipiński, S.A. (2007). Australian ladybird beetles (Coleoptera: Coccinellidae) their biology and classification. Australian Biological Resources Study: Canberra, Australia.

Sneath, P.H.A. and Sokal, R.R. (1973). Numerical taxonomy: the principles and practice of numerical classification. Freeman: San Francisco, U.S.A.

Solem, A. and McKenzie, N.L. (1991). The composition of land snail assemblages in Kimberley rainforests (pp 247-263). In: McKenzie, N.L., Johnston, R.B. and Kendrick, P.G. (eds), Kimberley rainforests. Surrey Beatty \& Sons: Chipping Norton, Australia.

Stebnicka, Z.T. and Howden, H.F. (1994). A revision of the Australian genus Podotenus A. Schmidt (Coleoptera: Scarabaeoidea: Aphodiini). Invertebrate Taxonomy 8: $17-62$.

Stebnicka, Z.T. and Howden, H.F. (1995). Revision of Australian genera in the tribes Aphodiini, Aegialiini and Proctophanini (Coleoptera: Scarabaeidae: Aphodiinae). Invertebrate Taxonomy 9: 709-766.

Stebnicka, Z.T. and Howden, H.F. (1996). Australian genera and species in the tribes Odontolochini, Psammodiini, Rhyparini, Stereomerini and part of the Eupariini (Coleoptera: Scarabaeoidea: Aphodiinae). Invertebrate Taxonomy 10: 97-170.

Stebnicka, Z.T. and Howden, H.F. (1997). Revision of the Australian species of Ataenius Harold (Coleoptera: Scarabaeoidea: Aphodiinae: Eupariini). Invertebrate Taxonomy 11: 735-821.

Storey, R.I. (1991). New species and new records of Tesserodon Hope (Coleoptera: Scarabaeidae) from northern Australia. Memoirs of the Queensland Museum 30: 577-588.

Yeates, D.K., Harvey, M.S. and Austin, A.D. (2003). New estimates for terrestrial arthropod species-richness in Australia. Records of the South Australian Museum Monograph Series 7: 231-241. 


\section{APPENDIX 1}

Sampling dates for invertebrates in wet pitfall traps in all survey quadrats.

See CD inside the back cover, or visit:

http://www.museum.wa.gov.au/research/records-supplements/attachments

\section{APPENDIX 2}

Frequency of occurrence across quadrats of all species in the families Bolboceratidae, Carabidae, Hybosoridae, Scarabaeidae and Tenebrionidae, collected in wet pitfall traps in each of the 24 survey cells. Number of sampled quadrats in each cell: NW-9; DRC, MBE, OYE, PHYC-11; PE, RHNE, TCMBC,

WYW-12; BDRN, BDRS, DRE, DRW, MBW, NE, OYW, PW, PHYE, PHYW, RHNC, RHNW, TCMBE, TCMBW, WYE-13.

See CD inside the back cover, or visit:

http://www.museum.wa.gov.au/research/records-supplements/attachments

\section{APPENDIX 3}

Data matrix re-ordered according to quadrat compositional similarities and species co-occurrences. Classification partition boundaries are shown at the 3-group level for the quadrats plus sub-groups; and at the 6-group level for species (for illustrative purposes only).

See CD inside the back cover, or visit:

http://www.museum.wa.gov.au/research/records-supplements/attachments

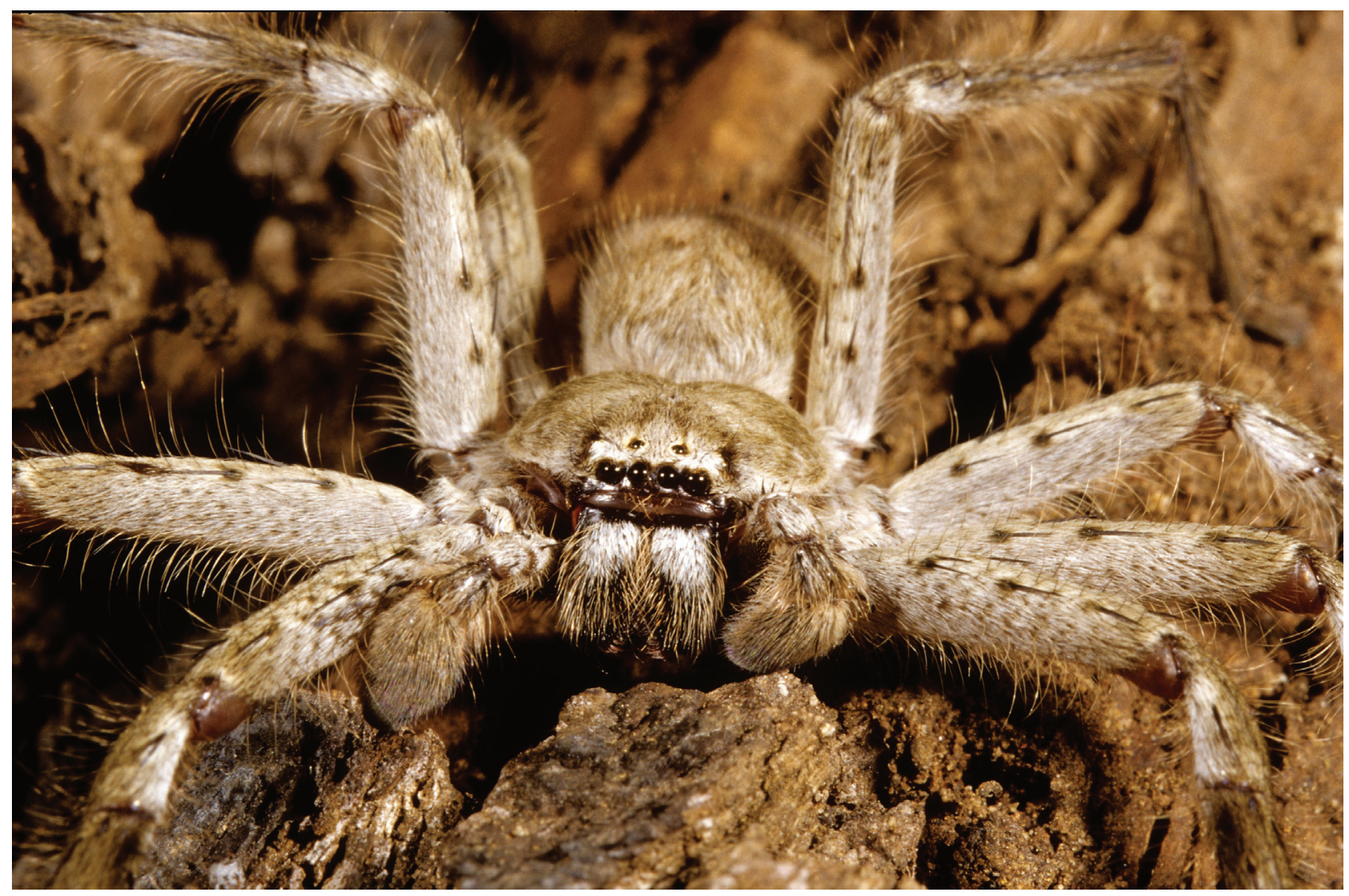

Huntsman spiders (Sparassidae) live under bark and in rocky areas (Lochman). 